\title{
Strategi Bertahan Pelaku Usaha Wisata dalam Menghadapi Pandemi Covid-19
}

\author{
Sucipto, Dede Nurohman \\ Fakultas Ekonomi Bisnis Islam, UIN Sayyid Ali Rahmatullah, Tulungagung \\ sucip1978@gmail.com \\ de2nur71@gmail.com
}

\begin{abstract}
The Corona Virus Disease-19 (covid 19) which is still ongoing has an impact on all aspects of people's lives, one of which is in the economic sector that is engaged in the tourism business. Since the implementation of Large-Scale Social Restrictions (PSBB) in various regions, the movement of people from one area to another is very limited. This was accompanied by an appeal from the government to temporarily stay at home to prevent the spread of covid 19, so that the number of tourists decreased to almost none. This paper examines the Brond Waterpark, one of tourism in the form of swimming pool rentals located in Tulungagung. The objectives of this study are: to determine the impact experienced by Brond Waterpark during the pandemic and to determine the survival strategy of this business in dealing with the pandemic. This study uses a descriptive method with a qualitative approach. Data was collected by using observation, interview, and documentation methods. The results of the study state that the strategies carried out by Brond Waterpark include: implementing strict and serious health protocols, keeping tourist attractions clean, digital marketing strategies, and collaborating with several schools.
\end{abstract}

Keywords: business strategy, business survival strategy, business management

\begin{abstract}
ABSTRAK
Corona Virus Desease-19(covid-19) yang sekarang masih berlangsung berdampak pada seluruh aspek kehidupan masyarakat, salah satunya ada pada sektor ekonomi yang bergerak pada usaha pariwisata. Sejak di berlakukannya Pembatasan Sosial Berskala Besar (PSBB) di berbagai daerah, menyebabkan pergerakan masyarakat dari daerah satu ke daerah lain sangat terbatas. Hal ini dibarengi dengan adanya himbauan dari pemerintah untuk sementara waktu tinggal di rumah saja untuk mencegah penyebaran covid 19, sehingga jumlah wisatawan menurun bahkan hampir tidak ada. Tulisan ini mengkaji Brond Waterpark, salah satu pariwisata dalam bentuk penyewaan kolam renang yang berada Tulungagung. Tujuan dari penelitian ini yaitu: untuk mengetahui dampak yang dialami Brond Waterpark pada saat pandemi dan untuk mengetahui strategi bertahan usaha ini dalam menghadapi pandemic tersebut. Penelitian ini menggunakan metode deskriptif dengan pendekatan kualitatif. Pengumpulan data dilakukan dengan metode observasi, wawancara, dan dokumentasi. Hasil penelitian menyebutkan bahwa strategi yang dilakukan Brond Waterpark antara lain: penerapan protokol kesehatan secara ketat dan serius, menjaga tempat wisata tetap bersih, strategi pemasaran secara digital, dan bekerja sama dengan beberapa pihak sekolah.
\end{abstract}

Kata Kunci : strategi bisnis, strategi bertahan bisnis, manajemen bisnis 


\section{PENDAHULUAN}

Di awal tahun 2020 ini, dunia dikagetkan dengan kejadian infeksi berat dengan penyebab yang belum di ketahui, yang berawal dari laporan dari Cina kepada Word Health Organization (WHO). Pada 10 Januari 2020 penyebabnya mulai teridentifikasi dan didapatkan kode genetiknya yaitu virus corona. Virus corona ini memiliki hubungan dekat dengan virus yang mewabah di Hongkong pada tahun 2003, hingga WHO memberikan nama sebagai novel corona virus (nCov-19). Tidak lama kemudian mulai muncul laporan dari provinsi lain di Cina dan di luar Cina yaitu ancaman pandemik semakin besar ketika berbagai kasus menunjukkan penularan yang terjadi antar manusia (human to human transmission) pada dokter dan petugas medis yang merawat pasien (Davies 2002). Corona Virus Desease-19 (Covid-19) yaitu virus yang menyerang sistem pernafasan dan bisa menyebabkan gangguan ringan pada sistem pernafasan, infeksi paru-paru yang berat, hingga kematian. Tatanan normal baru yaitu sebuah perubahan budaya hidup agar masyarakat dapat terbiasa dengan tatanan hidup normal yang baru untuk menghadapi penyebaran virus corona (Kiswantoro 2021).

Dampak pandemi menyebabkan semua sektor kehidupan di masyarakat harus berubah salah satunya di sektor agama. Dengan adanya pendemi Covid19 ini, semua budaya yang dilakukan saat bulan ramadhan mengalami perubahan dan semua bayangan tentang bulan suci ramadhan pupus. Bahkan sepertinya Masjid akan Sunyi untuk melakukan kegiatan shalat Tarwih (Fajar et al. 2020). Akibat dari pandemi covid19 ini, menyebabkan diterapkannya berbagai kebijakan seperti himbauan untuk menjaga jarak diantara masyarakat, menjauhi aktivitas dalam segala bentuk kerumunan, perkumpulan, dan menghindari adanya pertemuan yang melibatkan banyak orang. Dengan adanya pembatasan interaksi, Kementerian Pendidikan di Indonesia juga mengeluarkan kebijakan yaitu dengan meliburkan sekolah dan mengganti proses Kegiatan Belajar Mengajar (KBM) dengan menggunakan sistem dalam jaringan (daring) (Siahaan et al. 2020). Selain itu juga terjadi penurunan pertumbuhan ekonomi yang cukup drastis sebagai dampak Pandemi COVID-19. Bahkan tingkat pertumbuhan ekonomi pada masa 
pandemi tersebut menjadi yang terendah se-lama periode lima tahun terakhir (Aeni 2021).

Dampak ekonomi akibat adanya Covid-19 secara khusus dapat disebutkan antara lain menurunnya kegiatan konsumsi rumah tangga karena daya beli yang menurun, kegiatan insvestasi menurun, kegiatan ekspor dan impor juga menurun, dan juga kegiatan moneter. UMKM sebagai pilar penting dalam pertahanan ekonomi di sektor riil juga terguncang. Sektor ini biasanya tahan dari berbagai krisis. Pada saat krisis moneter 1997 sampai dengan 1998 dan juga saat krisis ekonomi global 2008, sektor UMKM ini masih bisa bekerja dengan baik memenuhi kebutuhan pasar. Namun pada situasi sekarang ini, sektor ini terkena dampak paling terasa. Karena mereka tidak bisa memproduksi karena masyarakat tidak mempunyai daya beli, masyarakat tinggal di rumah tidak bekerja. Karena itulah dampak ekonomi menjadi semakin luas di masyarakat. Situasi ini bisa membuat tingkat pertumbuhan ekonomi menurun drastis, bahkan bisa sampai pada nilai negatif dan menyebabkan perekonomian Indonesia semakin buruk karena salah satu indikator baik buruknya perekonomian disuatu daerah adalah dengan melihat tingkat pertumbuhan ekonominya (Gani 2017). Adanya pandemi tersebut juga berdampak bagi sektor pariwisata, mengingat bahwa dengan adanya virus Covid-19 pemerintah mengeluarkan berbagai kebijakan seperti halnya lockdown dan Pembatasan Sosial Berskala Besar (PSBB) yang mempengaruhi arus pergerakan manusia. Hal tersebut membuat pengunjung yang datang ke tempat wisata mengalami penurunan yang juga berpengaruh terhadap sektor pendapatan (Ananta and Rizkon 2020).

Pariwisata adalah kegiatan manusia yang melakukan perjalanan dengan tujuan bersenang-senang bahkann melakukan usaha bisnis. Pariwisata menjadi salah satu faktor dalam meningkatkan sumber pendapatan diluar pajak. Dengan adanya pariwisata, maka suatu negara atau pemerintah daerah tempat objek wisata itu berada, akan mendapat pemasukkan. Usaha pariwisata adalah kegiatan yang bertujuan menyelenggarakan jasa pariwisata yang menyediakan atau mengusahakan objek dan daya tarik wisata, karena aktivitas berwisata bagi individu dapat meningkatkan daya kreatif, menghilangkan kejenuhan, 
relaksasi, mengetahui peninggalan sejarah dan budaya suatu etnik tertentu. Dunia pariwisata adalah salah satu dari industri gaya baru yang mampu menyediakan pertumbuhan ekonomi yang begitu cepat dalam hal penyerapan kesempatan kerja serta peningkatkan pendapatan dan taraf hidup masyarakat sekitar. Berkembangnya pariwisata di suatu daerah akan mendatangkan banyak manfaat baik secara ekonomis, sosial dan budaya. Hal ini sesuai dengan perintah Allah surat An Nisa ayat 100:

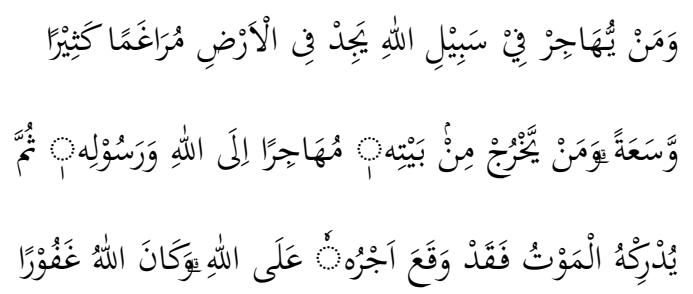

"Barangsiapa berhijrah di jalan Allah, niscaya mereka mendapati di muka bumi ini tempat hijrah yang luas dan rezeki yang banyak. Barang siapa keluar dari rumahnya dengan maksud berhijrah kepada Allah dan RasulNya, kemudian kematian menimpanya (sebelum sampai ke tempat yang dituju), maka sungguh telah tetap pahalanya di sisi Allah. Dan adalah Allah Maha Pengampun lagi Maha Penyanyang."
Perkembangan sektor pariwisata khususnya wisata halal merupakan sebuah keniscayaan di tengah dinamika perkembangan sektor pariwisata. Terminologi wisata dalam konteks Islam diperbolehkan sepanjang tidak keluar dari aturan yang ditetapkan oleh Allah Subhanahu Wa Ta'ala (Azizah 2021).

Kabupaten Tulungagung merupakan salah satu kabupaten yang berada di Provinsi Jawa Timur. Kabupaten Tulungagung terkenal sebagai satu dari beberapa daerah penghasil marmer terbesar di Indonesia. Kondisi perekonomian masyarakat Tulungagung mengalami perkembangan yang sangat pesat. Hal ini bisa dilihat dari sektor perdagangan, UMKM dan transportasi. Dilihat dari indeks harga konsumen yang tergambarkan dalam tingkat inflasi di Tulungagung sebelum adanya Covid-19 cukup terkendali. Tingkat inflasi tiga bulan sebelum kasus pertama tidak sampai angka $3 \%$ yaitu $2,98 \%$ di bulan Februari, 2.96\% di bulan Maret, dan 2.67\% di bulan April.10 Dari data tersebut menunjukkan daya beli masyarakat Tulungagung masih tinggi tetapi ada potensi daya beli masyarakat turun akibat Covid-19 (Gani 2017). Kabupaten Tulungagung memiliki potensi pariwisata yang melimpah. 
Adapun wisata yang terdapat di Tulungagung berupa wisata alam, wisata buatan, wisata sejarah/religi, wisata budaya, wisata edukasi, wisata bahari, dan wisata kuliner. Sedangkan wisata alam yang ada di Tulunggagung berupa pantai, gua, candi dan air terjun. Selain wisata alam, di Tulungagung juga terkenal dengan adanya wisata buatan salah satunya yaitu wisata air (waterpark). Banyak sekali wisata air yang berada di Tulungagung antara lain: (1) Jambooland Waterpark yang terletak di Karanganom, Tulungagung, (2) Splash Waterpark yang terletak di Bendilwungu, (3) Kolam Renang Tirta Kencana yang terletak di Kedungwaru, Tulungagung, (4) Kolam Renang Wardana yang terletak di Rejoagung, Kedungwaru, Tulumgagung, (5) Kolam Renang Hotel Crown Victoria yang terletak di Jepun, Tulungagung, dan (6) Brond Waterpark yang terletak di Sobontoro, Boyolangu, Tulungagung (http://jejakpiknik.com/kolam-renangdi-tulunggung, 2021).

Melihat paparan data di atas, banyak sekali wisata air (waterpark) buatan yang ada di Tulungagung. Salah satunya yaitu Brond Waterpark yang berada di Sobontoro Boyolangu Tulungagung. Brond Waterpark diresmikan pada tanggal 16 Desember 2019. Meskipun wisata yang terbilang baru, pengunjung yang datang di Brond Waterpark terus mengalami kenaikan pada setiap bulan. Ini bisa dilihat dari jumlah pengunjung empat bulan sebelum corona masuk Indonesia. Pada bulan Desemeber 2019 jumlah pengunjung mencapai 1000 orang, Januari 2020 naik 50\% atau sekitar 1500, Februari naik menjadi 1850, dan Maret mencapai 2100. Perkembangan jumlah pengunjung ini menunjukkan bahwa Brond Waterpark mengalami kenaikan cukup signifikan. Pada empat bulan berikutnya; April, Mei, Juni, dan Juli, bersamaan dengan kebijakan pemerintah yang sangat ketat untuk mencegah menyebarnya Covid19, usaha kolam renang ini mengalami penurunan drastis, bahkan dilarang untuk membuka usaha. Pada bulan Agustus, kolam renang ini mulai dibuka dengan protokol kesehatan yang sangat ketat. Pada bulan ini jumlah pengunjung hanya 100 orang. Perlahan-lahan hingga akhir tahun terus mengalami peningkatan hingga mencapai 512 orang. Masuk tahun 2021 jumlah pengunjung terus meningkat hingga di bulan Maret mencapai 864 pengunjung. Masuk bulan Juli kondisi pandemi gelombang kedua melanda Indonesia kembali hingga turun 
drastis menjadi 100 pengunjung (Profil Brond Water Park Sobontoro). Melihat kondisi di atas, usaha kolam renang Brond Waterpark sangat menjanjikan dan prospektif. Ini bisa dilihat dari data di atas bahwa meskipun situasi pandemi menyelimutinya, Ketika dibuka dengan protokol kesehatan ketat, kolam renang ini kembali mengalami peningkatan. Brond Waterpark termasuk usaha yang bersifat pleasure, yang dapat menghilangkan kepenatan kerja. Lokasinya yang dekat dengan kota membuat kolam renang ini menjadi pilihan utama masyarakat, semua kalangan, baik orang dewasa maupun anak-anak dalam memenuhi kebutuhan menghilangan kejenuhan mereka di kantor dan sekolah.

Tulisan ini ingin membahas mengenai Strategi Bertahan usaha kolam renang Brond Waterpark dalam Menghadapi Pandemi Covid-19. Secara lebih fokus tulisan ini ingin mengetahui cara-cara apa saja yang dilakukan Brond Waterpark dalam mengelola usahanya sehingga bisa bertahan di tengah pandemi Covid-19.

\section{TINJAUAN PUSTAKA}

\section{Strategi Bisnis}

Strategi merupakan rencana yang disatukan, luas dan berintegrasi yang menghubungkan keunggulan strategis perusahaan dengan tantangan lingkungan, yang dirancang untuk memastikan bahwa tujuan utama dari perusahaan dapat dicapai melalui pelaksanaan yang tepat oleh organisasi (Ii 2013). Dalam strategi yang baik terdapat kordinasi tim kerja, memiliki prinsip-prinsip pelaksanaan gagasan secara rasional, efesiensi dalam pendanaan dan memiliki taktik untuk mencapai tujuan secara efektif (Fendi Tjiptono, 2000). Pearce II dan Robinson $\mathrm{Jr}$ (2013) mengungkapkan strategi merupakan rencana skala besar yang berorientasi jangka panjang untuk berinteraksi dengan lingkungan yang kompetitif untuk mencapai tujuan perusahaan (Maulana 2018).

Bisnis merupakan salah satu aktivitas usaha yang utama dalam menunjang perkembangan ekonomi. Pengertian bisnis secara umum dalam ekonomi yaitu bisnis adalah suatu organisasi yang menjual barang atau jasa kepada konsumen atau bisnis lainnya, untuk mendapatkan laba. Secara etimologi, bisnis berarti keadaan dimana 
seseorang atau sekelompok orang sibuk melakukan pekerjaan yang menghasilkan keuntungan. Penggunaan kata bisnis dapat merujuk pada badan usaha yaitu kesatuan yuridis (hukum), teknis, ekonomis yang bertujuan mencari laba (Jonhannes 2007). Skinner (1992) mendefinisikan bisnis sebagai pertukaran barang atau jasa yang saling menguntungkan atau memberi manfaat (Mayssara A. Abo Hassanin Supervised 2014). Bisnis adalah sebuah aktivitas yang mengarah pada peningkatan nilai tambah melalui proses penyerahan jasa, perdagangan atau pengolahan barang (produksi) (Mayssara A. Abo Hassanin Supervised 2014).

Dari uraian pengertian strategi dan bisnis di atas, dapat disimpulkan bahwa strategi bisnis adalah cara untuk mencapai tujuan jangka panjang dalam usaha dagang, usaha komersial di dunia perdagangan atau bidang usaha yang meliputi aktivitas produksi dan penjualan barang-barang dan jasa-jasa yang diinginkan oleh konsumen guna memperoleh profit. Strategi bisnis bisa berupa perluasan geografis, diversifikasi, akusisi, pengembangan produk, penetrasi pasar, rasionalisasi karyawan, divestasi, dan likuidasi (Ii 2013).

\section{Strategi Bertahan Bisnis}

Setiap pebisnis tentu menginginkan usahanya sukses dan tetap survive di tengah pandemi corona ini. Ada kiat-kiat tertentu agar bisnis tetap survive walau di landa badai. Berikut strategi yang dapat digunakan untuk mempertahankan bisnis di tengah pandemi: 1) Memiliki kepercayaan diri dan kemandirian yang tinggi. Tanpa kepercayaan yang tinggi bisnis tidak dapat berjalan karena tidak berani untuk menanggung segala risikonya, 2) Berbisnis yang halal, mulai dari modal, proses, hingga penjualan, 3) Menjaga kepercayaan relasi bisnis dengan memberikan servis yang baik dan memuaskan, 4) Melakukan promosi barang dan jasa yang diperdagangkan, 5) Kepemimpinan. Seorang pemimpin harus memiliki jiwa kepemimpinan, mudah beradaptasi dengan orang lain, dan terbuka dengan saran dan kritik, 6) Menggunakan teknologi informasi dalam berbisnis (Frida 2020).

\section{Manajemen Bisnis}

Secara bahasa, pengertian manajemen bisnis diambil dari dua kata yaitu manajemen dan bisnis. Manajemen sendiri merupakan ilmu yang berhubungan dengan berbagai hal yang terkait dengan pengaturan, perancangan dan pengawasan dari suatu kegiatan 
termasuk juga bisnis (Ii n.d.). Menurut Marg Parker Foler, manajemen merupakan seni untuk menyelesaikan sesuatu melalui kinerja orang lain. Seni ini juga merupakan cara untuk bisa mencapai suatu tujuan tertentu yang dapat memberikan keuntungan bagi seluruh organisasi (Ii n.d.). Bisnis meiliki definisi sebagai satu jenis yang bertujuan untuk menjual produk-produk dalam bentuk barang maupun jasa. Dapat disimpulkan bahwa pengertian manajemen bisnis adalah suatu kegiatan mengatur penjualan produk-produk agar dapat memberikan keuntungan sebesar besarnya pada para pelakunya (Ii n.d.). Manejemen bisnis berguna untuk membantu para pelaku bisnis dalam menjalankan bisnisnya sehingga dapat menghindari adanya resiko mendapatkan kerugian dalam bisnis tersebut (Ii n.d.).

Perencanaan (planning) adalah penetapan pekerjaan yang harus dilaksanakan olek kelompok untuk mencapai tujuan yang di inginkan. Perencanaan mencakup kegiatan pengambilan keputusan, karena termasuk dalam pemilihan alternatifalternatif keputusan. Diperlukan kemampuan untuk mengadakan visualisasi dan melihat ke depan guna merumuskan suatu pola dari himpunan tindakan untuk masa mendatang (Ii n.d.). Proses perencanaan meliputi: 1) menentukan tujuan perencanaan, 2) menentukan tindakan untuk mencapai tujuan, 3) mengembangkan dasar pemikiran kondisi mendatang, 4) mengidentifikasi cara untuk mencapai tujuan, dan 5) mengimplementasi rencana tindakan dan mengevaluasi hasilnya (Ii n.d.).

Manajer sumber daya manusia dalam organisasi harus dapat memilih karyawan dari setiap divisi untuk mendapatkan karyawan-karyawan yang potensial sehingga dapat menduduki posisi tertentu sesuai dengan potensi, latar belakang pendidikan, dan keahlian yang dimiliki oleh karyawan. Pemilihan karyawan dari dalam organisasi memiliki dua manfaat penting. Pertama dari sisi manajemen, pemilihan karyawan dari dalam organisasi akan menguntungkan perusahaan karena karyawan sudah mengenal dengan baik budaya organisasi yang ada, menghemat biaya perekrutan, biaya pelatihan, dan biaya-biaya lainya. Kedua dari sisi karyawan, pemilihan karyawan dari dalam organisasi dapat memotivasi karyawan dan meyakinkan karyawan bahwa perusahaan menerapkan sistem 
jenjang karir yang jelas (Tampubolon 2014).

Sebuah perubahan atau organisasi yang timbul dengan perkembangan saat ini terhadap open inovation yaitu kemampuan untuk bekerjasama dengan lingkungan luar. Kerjasama strategis perlu dilakukan, baik dengan pelanggan, supplier maupun pihak eksternal lainnya. Di masa lalu, kerja sama antara dua pihak dalam industri yang sama adalah bentuk yang paling populer dari kerja sama kedua belah pihak. Ada tiga bentuk kerjasama yang dapat membantu UKM menjadi lebih inovatif: (1) kerja sama antar perusahaan; (2) kerjasama dengan pemerintah; dan (3) kerjasama dengan lembaga penelitian (Buwana and Nursyamsiah 2018). Kerja sama dengan pelanggan tidak hanya memberikan manfaat dalam mengidentifikasi peluang pasar, tetapi juga mengurangi kemungkinan desain yang buruk pada tahap awal pengembangan produk. Dengan demikian, keterlibatan pelanggan dapat menyebabkan keuntungan dalam hal inovasi produk (Buwana and Nursyamsiah 2018).

Pelayanan berpusat pada upaya pemenuhan kebutuhan dan keinginan konsumen serta ketetapan penyampaiannya untuk mengimbangi harapan konsumen. Menurut Wyekof, definisi pelayanan adalah tingkat keunggulan yang diharapkan dan pengendalian atas tingkat keunggulan untuk memenuhi keinginan konsumen. Apabila pelayanan yang diterima sesuai dengan yang diharapkan, maka kualitas pelayanan di persepsikan baik dan memuaskan. Sebaliknya, jika pelayanan yang diterima lebih rendah dari pada yang diharapkan konsumen, maka kualitasnya di persepsikan buruk. Dengan demikian kualitas pelayanan tergantung pada kemampuan pemilik jasa dalam memenuhi harapan konsumen secara konsisten namun dinamis dengan mengikuti kebutuhan konsumen (Merdian 2007).

Pendapatan adalah kenaikan modal perusahaan akibat penjualan produk perusahaan (Maulana 2018). Arus masuk aktiva atau peningkatan lainnya atas aktiva atau penyelesaian kewajiban entitas (atau kombinasi dari keduanya) dari pengirim barang, pemberian jasa, atau aktivitas lainnya yang merupakan operasi utama atau operasi sentral perusahaan. Pendapatan sangat berpengaruh bagi keseluruhan hidup perusahaan, semakin besar pendapatan yang diperoleh maka semakin besar kemampuan perusahaan untuk 
membiayai segala pengeluaran dan kegiatan-kegiatan yang akan dilakukan oleh perusahaan. Selain itu pendapatan juga berpengaruh terhadap laba rugi perusahaan yang tersaji dalam laporan laba rugi maka, pendapatan adalah darah kehidupan dari suatu perusahaan (Maulana 2018).

\section{METODE PENELITIAN}

Penelitian ini berjenis kualitatif dengan menggunakan metode deskriptif. Menurut Nazir (2005:54) metode deskriptif yaitu suatu metode dalam meneliti status sekelompok manusia, suatu objek, suatu kondisi, suatu sistem pemikiran, ataupun suatu kelas peristiwa pada masa sekarang, dan penelitian ini bertujuan membuat deskripsi, gambaran atau lukisan secara sistematis, faktual dan akurat mengenai fakta-fakta, sifatsifat serta hubungan antar fenomena yang selidiki. Metode deskriptif yang dipilih karena penelitian yang dilakukan bertujuan untuk menggambarkan dengan jelas tentang objek yang di teliti secara alamiah (Solemede et al. 2020). Teknik pengumpulan data menggunakan wawancara, dokumentasi, dan obeservasi. Wawancara dilakukan secara langsung di tempat bersama pemilik sekaligus pengelola Brond Waterpark, karyawan bagian pengelola kolam, karyawan bagian pemasaran, karyawan bagian kasir, dan lima orang pengunjung. Dokumentasi dilakukan dengan mengumpulkan data-data seperti profil usaha, data pengunjung, dan data laporan keuangan. Sedangkan observasi dilakukan dengan mengamati situasi kolam renang, kondisi tempat parkir, dan kondisi kantin. Untuk melengkapi data, peneliti juga menelusuri data-data sekunder dalam bentuk buku-buku, makalah atau artikel, majalah, jurnal, web (internet), ataupun informasi lainnya yang berhubungan dengan judul penulisan untuk mencari hal-hal atau variabel yang berupa catatan, transkip, buku, surat kabar, majalah dan sebagainya yang berkaitan dengan strategi bertahan tempat pariwisata di masa pandemi Covid-19. Teknik analisis data yang digunakan dalam penelitian ini adalah metode analisis isi (Content Analysis). Analisis ini digunakan untuk mendapatkan inferensi yang valid dan dapat diteliti ulang berdasarkan konteksnya (Solemede et al. 2020). Dalam analisis ini akan dilakukan proses memilih, membandingkan, menggabungkan dan memilah berbagai pengertian hingga ditemukan yang relevan (Firman 2015). 


\section{HASIL DAN PEMBAHASAN}

\section{Dampak Pandemi Covid-19 Bagi}

\section{Brond Waterpark}

a. Penurunan pendapatan

Adanya covid-19 ini akan berdampak terhadap laju perekonomian khususnya pada sektor pariwisata. Dimana pada pandemi covid-19 ini terdapat beberapa kebijakan pemerintah guna menanggulangi penyebaran virus corona jenis terbaru ini. Dengan adanya kebijakan guna menanggulangi penyebaran covid-19 seperti adanya protokol kesehatan 3M (menjaga jarak, mencuci tangan, memakai masker) dan juga adanya kebijakan stay at home membuat ketakutan sendiri terhadap masyarakat saat mengunjungi tempat wisata.

Dengan begitu tidak dipungkiri membuat Brond Waterpark mengalami penurunan jumlah pengunjung hingga 90\% di awal pembukaan Brond Waterpark dimasa new normal pandemi covid-19 dan titik terburuknya mengalami penutupan 4 bulan saat pertama kali pandemi masuk di Kabupaten Tulungagung, yang tentunya berimbas terhadap penurunan pendapatan. Dan berikut ini merupakan hasil pendapatan kotor sebelum dan sesudah adanya pandemi covid-19 sebagai berikut:

Tabel 3

Perbandingan Pendapatan di Brond

Waterpark Sebelum dan Sesudah

Adanya Pandemi Covid-19

\begin{tabular}{|c|c|c|c|}
\hline $\begin{array}{c}\text { N } \\
\mathbf{0}\end{array}$ & Bulan & $\begin{array}{c}\text { Tah } \\
\text { un }\end{array}$ & $\begin{array}{c}\text { Jumlah } \\
\text { Pendapa } \\
\text { tan (Rp) }\end{array}$ \\
\hline 1 & $\begin{array}{c}\text { Desem } \\
\text { ber }\end{array}$ & 2019 & $\begin{array}{c}10.000 .0 \\
00\end{array}$ \\
\hline 2 & $\begin{array}{c}\text { Januari } \\
\text { 2020 }\end{array}$ & $\begin{array}{c}10.500 .0 \\
00\end{array}$ \\
\hline 3 & $\begin{array}{c}\text { Februa } \\
\text { ri }\end{array}$ & 2020 & $\begin{array}{c}10.850 .0 \\
00\end{array}$ \\
\hline 4 & $\begin{array}{c}\text { Maret } \\
2020\end{array}$ & $\begin{array}{c}20.100 .0 \\
00\end{array}$ \\
\hline & \multicolumn{3}{|c|}{ Setelah adanya Pandemi } \\
Covid-19 \\
\hline 5 & April & 2020 & 0 \\
\hline 6 & Mei & 2020 & 0 \\
\hline 7 & Juni & 2020 & 0 \\
\hline 8 & Juli & 2020 & 0 \\
\hline
\end{tabular}

Sumber: hasil dokumentasi

Dari hasil pendapatan di atas diperoleh dari wawancara dengan Rio selaku Manajer Brond Waterpark. Menurut pernyataan Bapak Rio dia menyatakan pendapatan Wisata Brond Waterpark yang mengalami penurunan pendapatan yang drastis di bulan Agustus pada saat awal pandemi Covid- 
19 masuk ke Tulungagung dan hingga mengalami penutupan total di bulan April-Juli.

Badan Pusat Statistik dalam artikel yang ditulis oleh Ivana Solemede, Dkk menyatakan bahwa Pandemi Covid 19 telah berdampak terhadap berbagai sektor dalam kehidupan manusia. Sektor pariwisata yang selama ini digadanggadang sebagai sumber kontribusi devisa terbesar kedua bagi Indonesia mengalami penurunan drastis. jumlah kunjungan wisatawan mancanegara Februari 2020 mengalami konstraksi hingga $30,42 \%$ dibandingkan Januari 2020, dan turun $28,85 \%$ dibandingkan dengan periode yang sama tahun lalu (Solemede et al. 2020).

b. Pengurangan Jumlah Karyawan Akibat Adanya Covid-19

Pandemi Covid-19 selain berpengaruh terhadap jumlah pengunjung dan pendapatan juga berpengaruh terhadap berkurangnya jumlah karyawan akibat penutupan wisata selama 4 bulan. Karyawan yang dimiliki di mana awalnya berjumlah 18 orang menjadi 13 orang karyawan yang tersisa di Brond Waterpark. Kebijakan ini dilakukan Hal tersebut dapat di lihat dari wawancara berikut ini: "iya di sini juga ada kebijakan pengurangan karyawan sebanyak 5 orang mas, yang awalnya berjumlah 18 orang sekarang tinggal 13 orang. Hal tersebut dikarenakan adanya penutupan tempat wisata ini yang membuat berkurangnya anggaran guna untuk menggaji karyawan". ( Hasil wawancara dengan Imam, karyawan Brond Waterpark)

Amalia Yunita dalam artikel yang ditulis oleh Walakula menyatakan bahwa sekitar 7.804 karyawan yang kehilangan pekerjaan lantaran di PHK (di rumahkan) oleh instansi tempat mereka bekerja berdasarkan survey online terhadap 50 operator dari 16 provinsi. Hal ini tentunya akan berpengaruh bagi devisa Negara, mengingat sektor pariwisata merupakan penyumbang devisa terbedar nomor $2 \mathrm{di}$ Indonesia. Maka hal tersebut sangat memprihatinkan kondisi sektor pariwisata (Walakula Y 2020). Menteri Ketenagakerjaan dalam artikel yang ditulis oleh Juaningsih menyatakan bahwa beberapa perusahaan yang sudah mengeluarkan kebijakan untuk memutus hubungan kerja mempunyai alasan bahwa mereka tidak memiliki dana yang cukup untuk memberi upah pada para pekerja (Juaningsih 2020). 
c. Kebijakan pemerintah terkait pembatasan social dan penutupan sementara sector usaha

Kebijakan ini merupakan kebijakan dilematis. Karena jika sector usaha ditutup dan pembatasan social diterapkan mengakibatkan aspek ekonomi makro terganggu. Namun jika dibiarkan dapat mengakibatkan keselamatan dan Kesehatan warga terancam. Karena itu, pilihan pemerintah dengan kebijakan penutupan sementara dan pembatasan social menjadi pilihan pahit yang harus dilakukan oleh semua pihak termasuk pengelola usaha WBP. Bagi BWP, kebijakan ini berdampak pada ditutupkan kolam renang BWP selama 4 bulan (hasil wawancara dengan satgas Covid-19). Bahkan pemerintah Kabupaten Tulungagung sendiri akan memberikan sanksi tegas apabila wisata tersebut nekat di buka di awal adanya Pandemi Covid-19 masuk di Tulungagung. Hal tersebut dikarenakan melonjaknya masyarakat yang terkena Virus Corona jenis terbaru ini di Tulungagung hingga Kabupaten Tulungagung di golongkan di zona merah dengan tingginya penularan Covid antar masyarakat di Kabupaten Tulungagung (Kahfi Dirga Cahya,
2021). Hal tersebut dapat di lihat dari wawancara berikut ini:

"ketika awal terjadinya Covid-19 kemarin pemerintah juga menganjurkan untuk menutup tempat wisata disini, di karenakan di Tulungagung sendiri banyak masyarakat yang terkena Covidd-19”. (Hasil wawancara dengan Rio, manajer Brond Waterpark)

Yurianto dalam artikel yang ditulis oleh Dian Herdiana menyatakan bahwa penyebaran Covid-19 yang cepat mendorong pemerintah melakukan berbagai upaya penanggulangan penyebaran COVID-19, salah satu upaya tersebut yaitu menerapkan berbagai kebijakan dalam menanggulangi penyebaran COVID-19 agar tidak meluas dan menginfeksi banyak masyarakat. Salah satu kebijakan yang berdampak langsung kepada sektor pariwisata yaitu adanya surat edaran tentang himbauaun untuk sementara tidak melaksanakan kegiatan operasional jasa usaha pariwisata dalam upaya kewaspadaan terhadap penularan covid19 (Herdiana 2020).

\section{Strategi bertahan dalam menghadapi}

\section{Covid-19}

Situasi yang tidak menentu yang berdampak pada menurunkan gairah ekonomi membuat semua pelaku 
ekonomi memutar otak untuk mencari cara yang tepat dalam mengelola usaha. Pengelola Brond Waterpark mempunyai cara-cara bertahan dalam menghadapi situasi tersebut antara lain:

a. Penerapan protokol kesehatan secara ketat dan serius

Jaminan Keselamatan dan Kesehatan kerja merupakan hal yang sangat penting dalam kegiatan apapun, dalam dunia pariwisata banyak kegiatan yang dilakukan oleh pihak pariwisata. Dalam hal ini perusahaan banyak yang menawarkan kegiatan wisata dengan memperhatikan keamanan dan Kesehatan kerja bagi para wisatawan dan pihak lain sebagai penanggung jawab dari kegiatan wisata yang ditawarkan (Adz Dzikri and Sukana 2019). Perilaku konsumen lebh menyukai produk yang tidak saja banyak pilihan tetapi juga menjamin keselamatannya (Viscusi, 1985). Selain itu para wisatawan juga mempertimbangkan citra suatu destinasi yang baik dari tempat wisata tersebut khususnya di sector pengelolaan keamanan pengunjung yang dilakukan oleh pengelola pariwisata (Suharto 2016).

$$
\text { Pentingnya partisipasi }
$$
masyarakat dapat memberikan kontribusi sebagai modal social dalam menjaga kawasan desa terutama di daerah sector pariwisata sehingga mencapai keberhasilan dan perkembangan tempat wisata (Sibarani 2018). Brond Waterpark tetap buka hingga saat ini juga tak lupa atas izin yang di keluarkan oleh satgas Covid-19, hanya saja membatasi jumlah pengunjung yang datang dan tetap menghimbau bagi para pengunjung untuk mematuhi protokol kesehatan seperti menjaga jarak, memakai masker dan mencuci tangan. Karena hal tersebut telah di anjurkan oleh Satgas Covid 19 Kabupaten Tulungagung. Hal tersebut dapat di lihat dari wawancara berikut ini: "meskipun disini tetap buka tapi juga harus mematuhi protokol kesehatan mas. Seperti selalu memakai masker dan membatasi jumlah pengunjung yang datang setiap harinya”. (Hasil wawancara dengan Rio, manajer Brond Waterpark)

WHO dalam artikel yang ditulis oleh M. Galieh Gunagama, Dkk menyatakan bahwa physical distancing sebagai salah satu langkah untuk menurunkan angka infeksi terhadap Covid-19. Hal tersebut mendorong munculnya inovasi tentang bagaimana tetap menghidupkan pariwisata tanpa perlu melakukan perjalanan di tengah 
pandemi (Gunagama, Naurah, and Prabono 2020).

b. Menjaga tempat wisata tetap bersih

Di masa pandemi Covid-19 masyarakat dituntut untuk selalu bersih dan higenis, oleh karena itu pihak wisata Brond Waterpark membuat kebijakan dengan meningkatkan dan menjaga kebersihan di area wisata sehingga membuat pengunjung merasa nyaman pada saat berkunjung ke Brond Waterpark di masa pandemi. Pihak wisata juga rutin melakukan maentenance dengan cara memberikan zat kaporit dengan takaran yang tepat dan selalu melakukan pengecekan terhadap filter kolam untuk menjaga kebersihan air. Di sisi lain pihak wisata juga melakukan perbaikan terhadap fasilitas dan sarana prasarana seperti perbaikan terhadap wahana permainan. Hal ini perlu dilakukan agar pekerja, pengujung, bebas dari Covid-19 sehingga aman untuk berkunjung. Selain itu mereka juga menerapkan praktik baru akomodasi makanan dan minuman bagi keamanan serta kesehatan para pengunjung seperti penggunaaan wadah makanan atau piring sekali pakai. Hal tersebut dapat di lihat dari wawancara berikut ini: "kalau kita selama penutupan tetap melakukan operasional mas, seperti contohnya tetap menjaga kebersihan air dengan cara memberikan zat kaporit dan melakukan pengecekan pada filter air. Selain menjaga kebersihan, kita juga melakukan perbaikan terhadap beberapa wahana permainan untuk kenyamanan para wisatawan". (hasil wawancara dengan Rio, manajer Brond Waterpark)

Wishnutama Kusubandio dalam artikel yang ditulis oleh Walakula menyatakan bahwa sektor pariwisata telah menyiapkan beberapa strategi untuk dijalankan antara lain: 1) mempersiapkan berbagai infrastruktur, 2) mendesign ulang destinasi wisata, 3 ) mengadakan pelaytihan bagi para pekerja di sektor pariwisata (Walakula Y 2020).

Hal yang menjadi sorotan belakangan ini adalah kondisi daya Tarik wisata terkait kondisi kebersihan yang ada di sekitar lingkungan wisata. Mulai banyak sampah yang berserakan di sembarang tempat yang di sebabkan oleh beberapa faktor salah satunya ulah seorang pengunjung yang membuang sampah sembarangan. Pengelolaan kebersihan di tempat wisata akan berjalan dengan baik dengan adanya kerjasama antar pihak 
pengelola wisata (Rofifah 2020). Selain itu dalam menjaga kebersihan tempat wisata juga bisa dilakukan dengan cara menjalin kerjasama dengan masyarakat sekitar melalui pendekatan Personal Social Responsibility (PSR). Konsep PSR dilandasi dengan adanya toleransi yang dilakukan untuk membantu orang lain (Ganiem and Pandjaitan 2020). Dalam menjaga kebersihan juga bisa dilakukan dengan cara mengadakan sosialisasi kebersihan, mengajak para pedagang untuk menjaga kebersihan dan menghimbau para pedagang untuk membersihkan tempat jualan (Yandri Setia Bakti 2018).

c. Strategi pemasaran dengan cara digital

Promosi tetap diberlakukan untuk tetap bisa bertahan Brond Waterpark dan juga biar tetap ada pengunjung. Apalagi di mana wisata kolam renang tak hanya di Brond Waterpark ini. Program agar tetap beroperasi Brond Waterpark selama pandemi Covid-19 sangat penting agar tidak kembali tutup lagi, walaupun tidak seramai sebelumnya. Brond Waterpark melakukan pemasaran melalui sosial media yaitu melalui Instagram @brondwaterpark yang memuat informasi mengenai operasional di Brond Waterpark maupun untuk memasarkan event yang dilaksanakan di Brond Waterpark. Untuk memperluas pengunjung Brond Waterpark juga memanfaatkan media sosial Facebook dengan nama akun Brond Waterpark dan tak lupa melakukan pemasaran di grubgrub Facebook untuk Kabupaten Tulungagung dan sekitarnya. Hal tersebut dapat di lihat dari wawancara berikut ini:

"Di sini Brond Waterpark juga melakukan promosi di media sosial seperti facebook dan instagram mas, karena kalau tidak melakukan promosi secara online tidak banyak masyarakat yang bisa melihat informasi perkembangan wisata kami”. (hasil wawancara dengan Dimas, admin Brond Waterpark)

Dredge dalam artikel yang ditulis oleh M. Galieh Gunagama, Dkk menyatakan bahwa internet dianggap sebagai alat pemasaran yang kuat dan efektif dalam pariwisata. Internet secara konsisten diterima sebagai sarana yang sangat berharga untuk mendistribusikan informasi dan komunikasi (Gunagama, Naurah, and Prabono 2020).

Sudah diketahui banyak sebuah perusahaan yang menggunakan strategi pemasaran secara tradisional (offline) dan hampir tidak ada pilihan 
baru untuk mendorong persaingan. Dan saat ini pemasaran secara online banyak dilakukan dengan kemungkinan dan opsi yang hampir tidak terbatas sehingga sebuah perusahaan dapat melakukan sebuah pemasaran produk secara luas dan dapat di ketahui oleh semua kalangan masyarakat (Schwarzl and Grabowska 2015). Dengan meningkatnya globalisasi ekonomi dunia, peluang pasar tampaknya tidak ada habisnya bagi Sebagian besar perusahaan. Akibatnya, berangkat dari strategi tradisional dan taktik, seorang manajer mencari cara yang unik dan invatif untuk bersaing lebih efektif secara lokal, regional dan global. Internet mendapat banyak perhatian dari dunia bisnis karena internet akan mempercepat sebuah informasi. Selain itu juga menyediakan ketersediaan universal dan kualitas informasi yang lebih tinggi. Internet juga menyediakan lingkungan yang berbeda secara fundamental untuk pemasaran internasional dan membutuhkan pendekatan yang berbeda (Bertha and Sutejo 2006).

Apalagi di tengah pandemic covid-19, pemasaran model online menjadi sangat penting karena konsumen atau pengunjung pariwisata dapat dengan mudah mengakses berbagi kegiatan dan perkembangan yang ada di tempat wisata setelah adanya pandemi Covid-19. Dengan adanya kemampuan teknologi yang dimiliki oleh pengelola pariwisata membuat sector pariwisata mudah beradaptasi dengan melakukan stratrgi promosi secara online yang dapat menjadikan tempat wisata berkembang cukup pesat (Lukiarti and Widodo 2021).

d. Bekerja sama dengan beberapa pihak sekolah

$$
\text { Melakukan kerja sama }
$$
dengan beberapa sekolah yang memiliki program olah raga renang mulai dari jenjang SD-SMA bahwasannya jika ada siswa yang akan berenang disini kami melakukan pemotongan harga tiket yang awalnya Rp. 10.000 menjadi Rp. 7.000 untuk satu orang, tetapi jika ada wali murid yang ikut masuk tetap membayar Rp. 10.000. Selain pemotongan harga tiket, untuk para guru yang mendampingi siswa-siswa nya berenang disini kami memberikan tiket masuk secara gratis. Hal tersebut dapat dilihat dari wawancara berikut ini:

“disini juga bekerja sama dengan pihak sekolah mas, seperti pemotongan harga tiket yang di berikan kepada anak-anak sekolah mulai dari SD, SMP bahkan SMA. Untuk harga tikat nya sendiri 
kalau untuk anak-anak sekolah kita beri harga Rp. 7.000 untuk 1 orang, tetapi kalau ada wali murid yang ikut masuk harga tiketnya tetap seperti harga normal Rp. 10.000. Selain pemotongan harga tiket, disini juga memberikan tiket gratis pada semua guru yang mendampingi muridnya saat berenang”. (wawancara dengan Dimas, admin Brond Waterpark)

\section{Wishnutama Kusubandio} dalam artikel yang ditulis oleh Ivana Solemede, Dkk mengemukakan bahwa strategi pemulihan destinasi wisata di tatanan new normal dengan melibatkan para pelaku industri pariwisata dan pelaku ekonomi atau organisasi lain yang nantinya diharapkan pariwisata dapat produktif dan aman dari Covid-19 (Solemede et al. 2020).

Kerjasama atau membangun jaringan dengan pihak luar dapat meningkatkan kualitas pelayanan yang bisa memberikan kepuasan terhadap seorang konsumen. Ketika pihak pengelola industri pariwisata memberikan pelayan yang baik, tidak menutup kemungkinan seorang pengunjung/konsumen yang datang akan lebih banyak. Hal tesebut dikarenakan pengunjung yang datang ke tempat wisata tidak hanya untuk menikmati wahana yang ada tetapi juga memerlukan pelayanan yang baik untuk mencapai kepuasan berkunjung (Septiani 2008). Moh Jafar Hafsah mengatakan bahwa pada dasarnya tujuan kerja sama adalah harus menimbulkan kesadaran dan saling mengutungkan kedua belah pihak. Bukan berarti kedua belah pihak harus memiliki kekuatan yang sama, tetapi kedua belah pihak harus memberi kontribusi sesuai dengan kekuatan masing-masing untuk meningkatkan sebuah penghasilan . Bowo dan Andy dalam pelaksanaan Kerjasama harus mencapai sebuah keuntungan Bersama, dalam upaya untuk mencapai keuntungan bersama di perlukan komunikasi yang baik bagi kedua belah pihak. Selain untuk meningkatkan sebuah keuntungan, kerjama juga dapat menjalin hubungan yang harmonis antara kedua belah pihak dan meningkatkan rasa kesetiakawanan antara organisasi yang satu dengan organisasi yang lain (Pelzer et al. 2017). Strategi Brond Waterpark cukup memberikan hasil bagi bertahannya usaha Brond Waterpark. Hal ini bisa dilihat dari jumlah pendapatan empat bulan pertama setelah dibuka kembali tempat wisata tersebut yang mengalami peningkatan. Pada 
bulan Agustus 2020 kolam renang ini mulai di buka kembali dan memperoleh pendapatan mencapai Rp 1.000.000. Perlahan-lahan hingga akhir tahun jumlah pendapatan terus mengalami peningkatan hingga bulan Desember mencapai Rp 4.450.000. Masuk tahun 2021 jumlah pendapatan yang di peroleh terus mengalami peningkatan hingga bulan Maret mencapai Rp 8.650.000.

\section{KESIMPULAN}

Pandemi menyebabkan sektor usaha mengalami keterpurukan karena adanya kebijakan dari pemerintah yang menerapkan Pembatasan Sosial Berskala Besar (PSBB). Brond Waterpark mengalami dampak yang cukup serius antara lain: penurunan pendapatan, pengurangan jumlah karyawan, dan mengalami penutupan sementara. Namun demikian, adanya pandemi bukan berarti kiamat bagi semua pelaku usaha. Cara-cara yang cerdas dapat menjadi strategi bagi bertahannya sektor usaha. Brond Waterpark menyiasati dampak pandemi itu dengan strategi penerapan protokol kessehatan secara ketat dan serius, menjaga tempat wisata tetap bersih, melakukan pemasaran dengan cara digital dan bekerja sama dengan pihak sekolah. Cara atau strategi yang dilakukan Brond Waterpark ini bisa menjadi inspirasi bagi pelaku usaha lain, khususnya yang bergerak di sektor wisata buatan dalam bentuk penyewaan kolam renang atau wisata air buatan (kolam renang).

\section{DAFTAR PUSTAKA}

Adz Dzikri, Muhammad Alif, and Made Sukana. 2019. "Penerapan Kesehatan Dan Keselamatan Kerja Pada Wisata Paralayang Di Gunung Banyak, Kota Batu, Provinsi Jawa Timur.” Jurnal Destinasi Pariwisata 7(2): 274.

Aeni, Nurul. 2021. "Pandemi COVID19: Dampak Kesehatan, Ekonomi, \& Sosial." Jurnal Litbang: Media Informasi Penelitian, Pengembangan dan IPTEK 17(1): 17-34.

Ananta, Henri, and Ahmad Rizkon. 2020. "Analisis Dampak Covid-19 Terhadap Sektor Pariwisata Sikembang Park Kecamatan Blado Kabupaten Batang." Faklutas Ilmu Pendidikan, Fakultas Ilmu Sosial, Fakultas Bahasa dan Seni, Universitas Negeri Semarang: 17.

Azizah, Lailatul. 2021. "Strategi Pengembangan Pariwisata Dalam Perspektif Islam Menggunakan Metode Analisis SWOT Halal Tourism." Jurnal Manajemen dan Inovasi (MANOVA) 4(2): 18-36.

Bertha, Oleh :, and Silvia Sutejo. 2006. 6 Jurnal Manajemen INTERNET MARKETING: KONSEP DAN PERSOALAN BARU DUNIA PEMASARAN. 
Buwana, Muhammad Akbar Langlang, and Siti Nursyamsiah. 2018. "Analisis Implementasi Inovasi Terbuka : Peran Kerjasama Eksternal Terhadap Inovasi Produk Dan Kinerja Perusahaan (Studi Empiris Pada Usaha Kecil Dan Menengah (UKM) Batik Di Yogyakarta)." Jurnal Manajemen dan Bisnis Indonesia 6(1): 45-64.

Davies, Peter D.O. 2002. "Multi-Drug Resistant Tuberculosis." CPD Infection 3(1): 9-12.

Fajar, Muhammad, Nurul Annisa, Andi Jurana Anggriana, and dkk. 2020. "Bunga Rampai Pandemi 'Menyingkap Dampak-Dampak Sosial Kemasyarakatan Covid19.'" IAIN Parepare Nusantara Press: 1-102.

Firman. 2015. "Analisis Data Dalam Kualitatif." Article (4): 1-13.

Frida, N. 2020. “ “... Strategi Mempertahankan Dan Mengembangkan Bisnis Di Tengah Pandemi COVID-19 Serta Mengetahui Dampak Perkembangan Dan Pertumbuhan COVID-19 Di ...." Jurnal Aktiva: Riset Akuntansi dan Keuangan 2(3): 28-36.

https://aktiva.nusaputra.ac.id/articl e/view/61.

Gani, Syukrinur A. 2017. "SKENARIO PERTUMBUHAN EKONOMI PASCA COVID-19 DAN KONDISI LEMBAGA KEUANGAN MIKRO SYARIAH." Angewandte Chemie International Edition, 6(11), 951952. 15(01): 29-39.

Ganiem, Leila Mona, and Rosmawaty Hilderiah Pandjaitan. 2020. "Membangun Lingkungan Sehat
Di Kawasan Wisata Pantai Sawarna." Jurnal Bakti Masyarakat Indonesia 2(2): 20-28.

Gunagama, M Galieh, Yumna Rana Naurah, and Arganis Ellyza P. Prabono. 2020. "Pariwisata Pascapandemi: Pelajaran Penting Dan Prospek Pengembangan." LOSARI : Jurnal Arsitektur Kota dan Pemukiman 5(2): 56-68.

Herdiana, Dian. 2020. "Rekomendasi Kebijakan Pemulihan Pariwisata Pasca Wabah Corona Virus Disease 2019 (Covid-19) Di Kota Bandung." Jurnal Master Pariwisata (JUMPA) 7: 1.

Ii, B A B. 2013. "Pengaruh Strategi Bisnis Dan Budaya Terhadap Desain Sistem Pengendalian Manajemen Pada Hotel Berbintang Di Jawa Tengah Dan Yogyakarta." (1): 21-46. "Repository.Unisba.Ac.Id." : 23-53.

Jonhannes, Brahim. 2007. "Ibrahim Jones Dan Sewu Lindawaty, Hukum Bisnis Dalam Persepsi Manusia Modern, (Bandung:PT Refika Aditama, 2007), Hal. 2518 13." Ibrahim Jonhannes \& Sewu Lindawaty: 13-56.

Juaningsih, Imas Novita. 2020.

"Analisis Kebijakan PHK Bagi Para Pekerja Pada Masa Pandemi Covid-19 Di Indonesia." Buletin Hukum dan Keadilan 4(1): 18996.

Kiswantoro, Amin. 2021. "Penyaluran Alat Pencegahan Dan Sosialisasi Protokoler Kesehatan Untuk Pelayanan Kunjungan Wisatawan Dalam Menghadapi New Normal Pasca Pandemi Covid-19.” Jurnal 
Abdimas Pariwisata 1(2): 38-51.

Lukiarti, Ming Ming, and Agustina Widodo. 2021. "Pariwisata Oleh Yayasan Lasem Heritage Pada Masa Pandemi Covid-19." : 14254.

Maulana, Asril. 2018. "Analisis Pendapatan Dan Beban Operasional Dalam Meningkatkan Laba Operasional Pada PT. Kharisma Pemasaran Bersama Nusantara (PT KPB Nusantara)." Jurnal Akuntansi 1(2): 25-27.

Mayssara A. Abo Hassanin Supervised, Affiifi. 2014. "Strategi Bisnis." Paper Knowledge . Toward a Media History of Documents.

Merdian, Wili Andri. 2007. “Analisis Pengaruh Kualitas Pelayanan Terhadap Kepuasan Pelanggan (Studi Kasus TIKI, Jl Mantrigawen Lor No 12 Yogyakarta)." Skripsi (12): 126.

Pelzer, Katrin et al. 2017. "Hubungan Kerja Sama Dengan Pihak Luar." Solid State Ionics 2(1): 1-10.

Rofifah, Dianah. 2020. "PENGELOLAAN KEBERSIHAN OBJEK WISATA BENTENG MORAYA DI TONDANO KABUPATEN MINAHASA." Paper Knowledge . Toward a Media History of Documents: 12-26.

Schwarzl, Susanne, and Monika Grabowska. 2015. "Online Marketing Strategies: The Future Is Here." Journal of International Studies 8(2): 187-96.

Septiani, Yosi Putri. 2008. "Strategi Pelayanan Untuk Meningkatkan Jumlah Pelanggan Di CV. Miki
Tour Solo." : 65-142.

Siahaan, Matdio et al. 2020. "Halaman:

1-3 Terakreditasi Peringkat 5

(SINTA 5) Sesuai SK

RISTEKDIKTI Nomor." Edisi

Khusus 1(1): 1410-9794.

http://ejurnal.ubharajaya.ac.id/inde x.php/JKI.

Sibarani, Ezra Minar. 2018.

"Universitas Sumatera Utara

Skripsi." Analisis Kesadahan Total dan Alkalinitas pada Air Bersih

Sumur Bor dengan Metode

Titrimetri di PT Sucofindo Daerah

Provinsi Sumatera Utara: 44-48.

Solemede, Ivana et al. 2020.

"STRATEGI PEMULIHAN

POTENSI PARIWISATA

BUDAYA DI PROVINSI

MALUKU ( Suatu Kajian Analisis

Di Masa Transisi Kenormalan

Baru )." Jurnal Ilmu Sosial

Keagamaan I(1): 69-86.

Suharto. 2016. "Studi Tentang

Keamanan Dan Keselamatan

Pengunjung Hubungannya Dengan

Citra Destinasi (Studi Kasus

Gembira Loka Zoo)." Jurnal

Media Wisata 14(1): 287-304.

Tampubolon, Hotner. 2014. Strategi

Manajemen Sumber Daya Manusia

Dan Perannya Dalam

Pengembangan Keunggulan

Bersaing.

Walakula Y. 2020. “Analisis Eksistensi

Pariwisata Indonesia Di Tengah

Situasi Pandemi Corona Virus

Disease (Covid19)." NOUMENA:

Ilmu Sosial Keagamaan I(1): 47

52.

Yandri Setia Bakti. 2018. "JOM FISIP

Vol. 5: Edisi II Juli - Desember

2018 Page 1." Jom Fisip 5(2): 1- 
Ad-Deenar: Jurnal Ekonomi dan Bisnis Islam, VOL: 5/NO: 02 DOI : 10.30868/ad.v5i02.1736
P-ISSN: 2356-1866

E-ISSN: 2614-8838

15. 
Ad-Deenar: Jurnal Ekonomi dan Bisnis Islam, VOL: 5/NO: 02 DOI : 10.30868/ad.v5i02.1736
P-ISSN: 2356-1866

E-ISSN: 2614-8838 